\section{Milica Đorđević ${ }^{1}$}

Ognjen Radović ${ }^{2}$

Ljiljana Bonić ${ }^{3}$

University of Niš,

Faculty of Economics
ORIGINAL SCIENTIFIC ARTICLE doi:10.5937/ekonomika1803023D

Received: Jun, 07, 2018

Accepted: September, 07, 2018

\title{
POTENTIALS FOR APPLYING CLOUD TECHNOLOGY IN ACCOUNTING
}

\begin{abstract}
Cloud technology, as an innovative way of data processing and storage, is one of the latest trends in the world of information technology. Adopting these technological solutions is one of the primary ways to ensure the efficiency of the accounting information system, so today the focus is more and more on cloud accounting, or, how it can often be heard, online accounting, web accounting, or virtual accounting system. The aim of this paper is to point to specific features of applying cloud technology in accounting - opportunities it provides, as well as risks arising from it. In addition, by presenting the benefits that cloud-based accounting brings to companies implementing this technology as well as users of financial information, the authors aim to encourage and stimulate companies in the Republic of Serbia to use the growing cloud services market and introduce this technology into their accounting information systems.
\end{abstract}

Key words: Cloud technology, accounting information system, cloud accounting

JEL classification: M410, L860

\section{ПОТЕНЦИЈАЛИ ЗА ПРИМЕНУ СLOUD ТЕХНОЛОГИЈЕ У РАЧУНОВОДСТВУ}

\begin{abstract}
Апстракт
Clои технологија, као иновативан начин процесуирања и чувања података, један је од најновијих трендова у свету информационих технологија. Усвајање решења која ова технологија пружа представља један од примарних начина обезбеђивања ефикаснсости рачуноводственог информационог система, те данас све више говоримо о сlои рачуноводству, односно како се често може чути, оп-linе рачуноводству, веб рачуноводству или виртуелном рачуноводственом систему. Циљ аутора овог рада је да укажу на специфичности примене сloиd технологије у рачуноводству - могућности које
\end{abstract}

\footnotetext{
${ }^{1}$ milica.djordjevic@eknfak.ni.ac.rs

${ }^{2}$ ognjen.radovic@eknfak.ni.ac.rs

${ }^{3}$ ljiljana.bonic@eknfak.ni.ac.rs
} 
пружа, али и ризике које из тога проистичу. Осим тога, представљањем бенефита које применом сlоид рачуноводства остварују не само предузећа која имплементирају ову технологију, већ и корисници финансијских информација, аутори имају за циљь да подстакну и охрабре предузећа у Репубилици Србији да искористе растуће тржиште сlои услуга и свој рачуноводствени информациони систем базирају на овој технологији.

Кључне речи: Cloud технологија, рачуноводствени информащиони систем, сlоид рачуноводство

\section{Introduction}

Today, companies operate in an environment where rapid technological development imposes constant changes in the ways information system functions, i.e. collection, processing, and exchange of information. The development of information technology (IT), supported by automation, enables the creation of new products, new industries, new markets, and thus ensures economic growth (Prichici, Ionescu, 2015, p. 490). The Internet has led to the emergence of a digital economy which companies can choose to accept or not, as part of their business strategy and a "source of power and authority" (Al-zoubi, 2017).

Undoubtedly, one of the most important trends in the IT area is cloud technology. It is a business model for the purchase and use of computer services, applications, access to information and data storage via an Internet connection. "Depending on the cloud solution model an organization adopts, all or parts of the organization's hardware, software, and data might no longer reside on its own technology infrastructure" (Warren et al., 2012, p. 2), so that the user does not know the physical location and configuration of the system that provides these services. Therefore, the cloud allows for fast and "ondemand" access to network, application, server, and so on, located on the cloud, with minimal effort to manage or interact with the service provider. Access is possible at any time, with an increasing number of devices and independently of a geographic location - only the Internet browser and connection is required.

The cloud technology concept and idea are surely revolutionary. This is the topic that is most talked about in the field of information technology (Ebenezer et al., 2014, p. 2) because it smoothly supports all business applications and services and responds to a whole range of business needs. Logically, accountants, who have never given up following trends in technological development (Wyslocka, Jelonek, 2015, p. 5), explore the possibilities that this technology provides. By identifying significant potentials for optimizing accounting activities using cloud-based applications, accountants give this technology an opportunity to prove its utility. Though it carries risks with it, cloud technology is becoming an increasingly acceptable technology solution in accounting, preserving the role of accountants in the digitalization era. 


\section{Specific features of cloud technology application in accounting}

In the past three decades, accounting information systems have applied accounting software for efficient reporting on company economic reality. Owing to continuous information technology development, these software solutions have been enhanced and become more sophisticated and more convenient in processing the growing volume of information. Thus, Phillips (Ionescu et al., 2013) distinguishes four generations of accounting software that he classifies into three time groups: (1) The first category dominates the 1990s, which implies simple applications, suitable for all users, regardless of their size, in which data and reports are under the client's strict control; (2) The 2000s include two software categories: the first one includes accounting applications using data stored locally or on servers, and the other one implies applications that can be simultaneously accessed by multiple users, relying on powerful databases stored in secure locations, and (3) since 2010, there is a period of "mobile" accounting software with financial "dashboards", whose application involves the use of the Internet and mobile devices. Based on this categorization, it is clear that the latest trend in applying information technology in accounting is cloud, from which the so-called cloud accounting has emerged.

Proceeding from the characteristics of cloud computing, cloud accounting involves the use of software for the collection and processing of data accessed through the Internetbased cloud provider's application. Therefore, the accounting software and data are located on the remote server, software installation and maintenance on individual computers are not necessary, and data "retrieval" by a large number of users is simultaneously possible at any moment from a large number of devices. Cloud technology application has by no means changed the function of accounting in relation to the use of traditional software. The main difference is that traditional accounting software is procured as "tangible" assets and installed on the user's computer system, while with cloud the user purchases the right to use software via the Internet (Software as a Service, SaaS) (Azad, 2013). This points to a difference in the application support provided (Ionescu, 2013, p. 7), in the sense that cloud platform supports the work of multiple users (in accordance with the authorizations they received), while traditional platforms are limited to a relatively small number of users. Differences in the application of traditional and cloud-based software are shown in Table 1.

Table 1. Differences in the application of traditional and cloud-based software

\begin{tabular}{|c|c|c|}
\hline & License only & Cloud based solution (Saas) \\
\hline Accounting software license & Company's own & Company rent it \\
\hline System location & Where company want it & In the cloud \\
\hline Hardware & Provided by company & Included \\
\hline Windows \& SQL Server & Provided by company & Included \\
\hline Maintenance fees & Purchased & Included \\
\hline IT Resources & Company team or a provider & None required \\
\hline Support & Purchased from a provider & Purchased from a service provider \\
\hline Number of users & Limited by license & Unlimited \\
\hline
\end{tabular}

Source: Christauskas, Miseviciene, 2012, p. 17 
Cloud technology, with all its characteristics, has a very positive impact on all elements of the accounting information system (Al-zoubi, 2017). Among other things, it significantly rationalizes the accounting function establishment in terms of providing space for work. This is because cloud technology allows access to applications and data from any site, the so-called virtual object, and any mobile device (laptop, phone, tablet, etc.). This, logically, increases the efficiency of recording and quantifying business transactions and events because the $24 / 7$ software availability allows accountants to perform their activities when they want, not strictly during working hours. Accounting software is easily accessed over the Internet, without previously checking compatibility between the computer system used and the accounting software. This ensures that all users access the same version of accounting software, thereby eliminating potential problems caused by incompatible versions (Ionescu, 2013, p. 6). This further transforms the relationship of accountants and their clients in terms of improving cooperation and communication. More precisely, distribution of files facilitating cloud recording of business changes ensures their continued availability and easier access to them. In this way, "eliminating the burden of data and file transmission" (Dimitriu, Matei, 2015, p. 670 ) increases collaboration between employees, as well as synchronization and work on shared files. A particular advantage of the software based on this technology is reflected in the automation of transaction recording through business books, thus ensuring compliance with various requirements including accounting standards and internal controls (Christauskas, Miseviciene, 2012, p. 15).

Significant advantages of cloud accounting, in comparison to traditional accounting, also result from the use of software as a service provided by the cloud provider, rather than software installed on the user's personal computer. These advantages are multiple: responsibility for hardware and software maintenance and management is the service provider's, which reduces the engagement of IT professionals; the level of data security, from the point of view of misuse and destruction risk, is considerably higher because most cloud service providers have better internal control of data access than control provided by an average enterprise, and, in addition, provide backup servers on two or more locations. Data storage in the "cloud" - if the device (laptop, tablet, etc.) is stolen or broken, eliminates the risk of data loss, because the same data can be accessed from another device (Dimitriu, Matei, 2015, p. 668); given that accounting software is easily adapted to business needs, cloud service providers may more often afford to add new software packages as needed or upgrade existing versions. What is highlighted as a particular benefit of using the software as a service is the ability to try out the software before the final decision on use. The majority of providers offer a trial period to allow a potential user to assess whether the service meets their needs (Christauskas, Miseviciene, 2012, p. 15). 
Figure 1: Use of cloud computing services in enterprises,

2014 and 2016 (\% of enterprises)

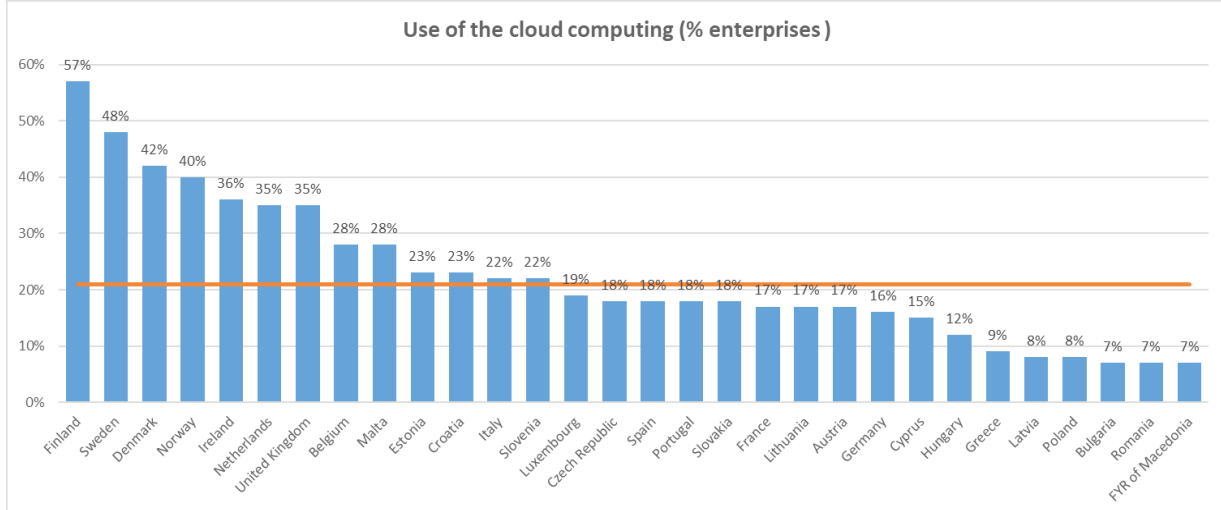

Source: Eurostat, 2016

According to Forrester predictions (European Cloud Alliance, 2017), aggressive growth of applications based on cloud computing is expected. The cloud market in the EU with a $15 \%$ share in 2015 should grow to $27 \%$ in 2018 .

The situation in the United States is much more favorable. According to the IDC CloudView Survey (2016), nearly $75 \%$ of US companies surveyed use public cloud services. In addition, $80 \%$ of US companies regularly using cloud services have contracts with multiple cloud providers. According to the same research, by 2020, the majority (54\%) of total IT spending will be allocated for public and private cloud solutions.

Table 2 shows the results of the survey conducted in the Republic of Serbia, which the Statistical Office of the Republic of Serbia does every year. The latest survey (2017) was conducted on a sample of 1655 enterprises with 10 or more employees.

Table 2: Usage ICT in the Republic of Serbia (2013-2017)

\begin{tabular}{|c|c|c|c|c|c|}
\hline & \multicolumn{5}{|c|}{ Year } \\
\hline & 2013 & 2014 & 2015 & 2016 & 2017 \\
\hline The enterprise pays cloud computing services & - & $3,8 \%$ & $9,2 \%$ & $9,3 \%$ & $9,3 \%$ \\
\hline $\begin{array}{l}\text { Internet population used cloud services to store or } \\
\text { share information (Google drive, Dropbox, iCloud) }\end{array}$ & - & $10,4 \%$ & $15,5 \%$ & $19,4 \%$ & $19,5 \%$ \\
\hline The enterprises have a website & $73,8 \%$ & $74,0 \%$ & $75,2 \%$ & $80,8 \%$ & $80,4 \%$ \\
\hline Broadband Internet connection in enterprises & $97,8 \%$ & $98,0 \%$ & $98,0 \%$ & $99,1 \%$ & $98,6 \%$ \\
\hline $\begin{array}{l}\text { Business use of social networks (Facebook, } \\
\text { Linkedln, Xing, Yammer) }\end{array}$ & $23,4 \%$ & $27,0 \%$ & $28,6 \%$ & $36,1 \%$ & $35,7 \%$ \\
\hline $\begin{array}{l}\text { Business use of multimedia content sharing sites } \\
\text { (Youtube, Flickr, Picassa) }\end{array}$ & $10,7 \%$ & $13,9 \%$ & $10,0 \%$ & $14,6 \%$ & $14,6 \%$ \\
\hline
\end{tabular}

Source: Eurostat, 2014. 
In a survey by the Statistical Office in 2014, respondents state that the main factors of limited cloud use are: high price of services (21.5\% of respondents), security risk (19.4\% of respondents), and insufficient knowledge of the use of cloud services $(17.2 \%$ of respondents).

Taking into account the studies mentioned, security of information is considered one of the most important factors for accepting cloud. Accordingly, providers must place greatest emphasis on providing the highest level of security and focus on current as well as potential users. In this context, two aspects need to be especially emphasized (Pfarr et al., 2013): first, the difference between the actual and the perceived security of information; second, enterprises based in the European Union are subject to strict laws, which prohibit the storage of certain information on servers outside the EU. Cloud providers as well as (potential) users need to bear in mind this aspect during the service selection phase.

Significant security and privacy factor in the context of cloud services is the establishment of standards (Pfarr et al., 2013). For example, ISO/IEC 27017 deals with the security of public cloud services, ISO/IEC 27018 standard deals with the protection of personal data for public cloud services. In addition, ISO/IEC 19086 series standards apply to cloud service agreements and SLAs. ISO/IEC19086-4 deals with security and privacy components of the cloud service level agreements. ISO/IEC 27036-4 provides guidelines on the security risks of information related to the use of cloud services and the efficient management of those risks.

Hawsons, an accounting firm in England with the longest tradition, suggests that, prior to selecting a cloud service provider, it is important to analyze the terms of cooperation well in order to make sure that the selected provider implements the necessary data protection controls. In that sense, it is important to observe: how regularly data protection controls are implemented, whether and what quality standards the provider meets, what security measures they take, which data encryption software they use, how often they archive server data, and so on (Hawsons Chartered Accountants). In addition, many influential accounting firms provide assurance services to guide companies in the process of adopting and maintaining cloud technology. Thus, Deloitte provides consultation services when choosing a cloud service provider, as well as when integrating this technology into accounting; KPMG focuses the largest segment of consulting on the field of data security. The assurance service involves reviewing agreements on protecting client rights and making sure that system data security standards are in place before accepting the service. Ernst and Young advises the client to make sure that a contract with a service provider includes urgent repairs and legal remedies for loss of business continuity (Kinkela, 2013). Treadway Commission issued "Enterprise Risk Management for Cloud Computing", in which it calls on the board of directors responsibility to manage risks posed by cloud technology. In this guide, the board is guided towards determining the acceptable risk level that this technology carries, adequate risk assessment to which the enterprise is exposed by its application, response to these risks, and the introduction of control activities in the establishment, implementation, and maintenance of this technology (Warreng et al., 2012). 


\section{Conclusion}

Information technology, and, undoubtedly, cloud computing, conditioned the revolutionary transformation of the accounting information system. While it is quite clear that this transformation does not imply the exclusion of human labor, but that its purpose is to ensure its optimization, accountants are still cautious in the adoption of this technology. As people are naturally most afraid of new things, the risks they indicate to justify their aversion to the implementation of this technology relate to: data security because the service provider has access to confidential information, and the feeling that users have no control and become dependent on the provider who is responsible for maintenance and management of the application, etc. Nevertheless, accountants claim that the benefits provided by this technology overcome the dangers it carries with it, so relevant professional organizations and accounting firms provide support to accountants in the adoption and implementation of this technology.

Previous research and studies have confirmed that enterprises, especially small and medium, are not aware of the benefits of adopting cloud solutions. This situation is especially alarming in the Republic of Serbia, where only $9.3 \%$ of enterprises use these services. The conducted surveys and studies highlight the need for training and awareness raising campaigns on the importance of adopting cloud solutions in the business world. In most surveys, enterprises point out that the risk of security breach is a key factor of aversion or less use of cloud services. Besides, enterprises, especially small and medium-sized, point to insufficient knowledge of cloud computing as a significant factor discouraging the use of cloud services, but also a factor that affects the poor perception of security issues. Finally, expertise and knowledge of contractual, legal, and technical aspects of implementation are prerequisites for an enterprise that decides to purchase cloud computing services.

\section{Reference}

Ace Cloud Hosting (2018). 10 Accounting Trends That Will Dominate 2018. https:// www.acecloudhosting.com/10-accounting-trends-that-will-dominate-2018/

Al-zoubi, M.A. (2017). The Effect of Cloud Computing on Elements of Accounting Information System, Global Journal of Management and Business Research: Accounting and Auditing, 17 (3), Преузето Фебруар 16, 2018 ca https:// journalofbusiness.org/index.php/GJMBR/article/view/2340

Capterra (2015). Accounting Software User Research Report. https://www.capterra. com/accounting-software/user-research

Christauskas, C., Miseviciene, R. (2012). Cloud - Domputing Based Accounting for Small to Medium Sized Business, Engineering Economics, 23 (1), 14-21

Azad, S. (2013). The Benefits of Cloud accounting. Преузето Фебруар 15, 2018 ca The Pitcher Partners Critical Point Network: http://www.pitcher.com.au/sites/ default/files/downloads/CPN_Newsletter_Spring_2013.pdf

Dimitriu, O., Matei, M. (2015). Cloud accounting: a new business model in a challengigng context. Procedia Economisc and Finance, 32, 665-671

Dimitriu, O., Matei. M., (2014). The Expansion of Accounting to the Cloud. SEA Practical Application of Scienc, 2 (4), 237-240 
Ebenezer, E., Omane-Antwi, K.B., Kyei, M. (2014). Accounting in the Cloud: How Cloud Computing Can Transform Businesses (The Ghanaian Perpective). Proceedings of the Second International Conference on Global Business, Economics, Finance and Social Sciences, India

Eurostat (2014, 2016) http://ec.europa.eu/eurostat/statistics-explained/index.php/ Cloud_computing_-_statistics_on_the_use_by_enterprises

European Cloud Alliance (2017). Cloud Trends to Follow in 2018: Cybersecurity, Digital Transformation and Privacy, https://www.europeancloudalliance.com/ wp-content/uploads/2017/12/Cloud-Trends-Report-2018-1.pdf

Hawson Chardered Accountants, A guide to cloud accounting - big benefits for small businesses. Преузето Фебруар 10, 2018 ca https://www.hawsons.co.uk/wpcontent/uploads/2015/03/A-guide-to-cloud-accounting.pdf

IDC (2016). Cloud Trends in 2017. https://www.business.att.com/content/whitepaper/ att-cloud-trends-data-migration-white-paper.pdf

Ionescu, B., Ionescu, I., Bendovschi, A., Tudoran, L. (2013). Tradicional Accounting vs. Cloud Accounting. Proceedings of the 8th International Conference Accounting and Management Information Systems - AMIS 2013, 105-125

Kinkela, K., College, I. (2013). Practical and ethical considerations on the use of cloud computing in accounting. Journal of Finance and Accountancy. Преузето Фебруар 15, 2018 ca http://www.aabri.com/manuscripts/131534.pdf

Pfarr, F., Chowanetz, M., Winkelmann, A., (2013). Critical Success Factors for Softwareas-a-Service Adoption. 7th IFAC Conference on Manufacturing Modelling, Management, and Control International Federation of Automatic Control, 325-330

Prichici, C., Ionescu, B., (2015). Cloud Accounting - A New Paradigm of Accounting Policies. SEA - Practical Application of Science, 1(7), 489-496

Rao, M.T., Jyotsna, T.G., Sivani, M.A., (2017). Impact of Cloud Accounting: Accounting Professional's Perspective, IOSR Journal of Business and Management (IOSR-JBM), 7, 53-59

Republički zavod za statistiku Republika Srbija (2015). Upotreba informacionokomunikacionih tehnologija u Republici Srbiji.

Sánchez, Pedro R. Palos (2017). Drivers and Barriers of the Cloud Computing in SMEs: the Position of the European Union, Harvard Deusto Business Research, 6(2), 116-132

Vićentijević K., Petrović Z., Jović Z., Glišović N., Rakočević S., Kaljević J., (2015). Upotreba cloud računovodstva $u$ odnosu na tradicionalno računovodstvo $u$ Republici Srbiji. Synthesis 2015 - International Scientific Conference of IT and Business-Related Research, 711-714.

Warreng, C., Leung, E., Pili, H. (2012). Enterprise Risk Management for Cloud Accounting. Committee of Sponsoring Organization of the Treadway Commission- COSO

Wyslocka, E., Jelonek, D., (2015). Accouting in the Cloud Computing. The Online Journal of Science and Techology, 5 (4), Преузето Фебруар 12, 2018 ca , https:// www.tojsat.net/journals/tojsat/articles/v05i04/v05i04-01.pdf 